\title{
TOXICITY EFFECTS OF CADMIUM IN GRASS CARP (CTENOPHARYNGODON IDELLA) AND BIG HEAD CARP (HYPOPHTHALMICHTHYS NOBILIS)
}

\author{
Mohammad FOROUHAR VAJARGAH * \\ and Aliakbar HEDAYATI ** \\ * Guilan University, Faculty of Natural Resources, Guilan, Iran, P.O. Box 816, IR-68536-65263, \\ mohammad.forouhar@yahoo.com \\ ** Gorgan University of Agricultural Sciences and Natural Resources, Faculty of Fisheries and \\ Environment, Basij Square, Daneshgah Boulevard, Gorgan, Iran, P.O. Box 219, IR-49316-15581, \\ Hedayati@gau.ac.ir
}

DOI: 10.1515/trser-2017-0004

KEYWORDS: Fish, Cadmium Chloride, Toxicity, 96 h LC L0. $_{5}$.

\section{ABSTRACT}

Heavy metals can threaten ecosystem health and of food security. The purpose of percent study was evaluating the sensitivity of grass carp (Ctenopharyngodon idella) and Big head carp (Hypophthalmichthys nobilis) exposed to cadmium Chloride. To this end, fishes were exposed different concentrations of cadmium in range of cadmium chloride $(0,0.2,1,2$, 6, 10 and $15 \mathrm{ml} / \mathrm{l})$. The mortality of treatments was calculated at intervals of 24, 48, 72, 96 hours. Analysis of the data showed the $96 \mathrm{~h} \mathrm{LC}_{50}$ of cadmium chloride for grass carp was $4.164 \mathrm{ml} / \mathrm{l}$ and for Big head carp was $5.590 \mathrm{ml} / \mathrm{l}$. The results of this study showed that Cadmium is highly toxic for freshwater species.

RESUMEN: Evaluar la toxicidad del cadmio en la carpa de hierba (Ctenopharyngodon idella) y en la carpa de cabeza grande (Hypophthalmichthys nobilis).

Los metales pesados pueden amenazar la salud de los ecosistemas y la seguridad alimentaria. El propósito del estudio porcentual fue evaluar la sensibilidad de la carpa herbívora (Ctenopharyngodon idella) y la carpa cabezona (Hypophthalmichthys nobilis) frente al cadmio. Con este fin, los peces fueron expuestos a diferentes concentraciones de cadmio en un rango de $0,0,2,1,2,6,10$ y $15 \mathrm{mg} / \mathrm{l}$ de cloruro de cadmio. La mortalidad en los tratamientos se calculó a intervalos de 24, 48, 72 y 96 horas. El análisis de los datos mostró que la LC50 de Cadmio (cloruro de cadmio) para la carpa herbívora a las 96 h fue de 4.164 $\mathrm{mg} / \mathrm{l}$ y para la carpa cabezona de $5.590 \mathrm{mg} / \mathrm{l}$. Los resultados de este estudio mostraron que el cadmio es altamente tóxico para las especies de agua dulce.

REZUMAT: Evaluarea toxicității cadmiului la amur (Ctenopharyngodon idella) și la novac (Hypophthalmichthys nobilis).

Metalele grele pot pune în pericol sănătatea mediului și securitatea alimentară. Prezentul studiu a avut ca obiectiv evaluarea sensibilității amurului (Ctenopharyngodon idella) și novacului (Hypophthalmichthys nobilis) la cadmiu. În acest scop, peștii au fost expuși la diferite concentrații de cadmiu sub formă de clorură $(0,0,2,1,2,6,10$ și $15 \mathrm{ml} / \mathrm{l})$. Mortalitatea indusă de administrări a fost calculată la intervale de 24, 48, 72 și 96 ore. Analiza datelor arată că LC50 a cadmiului (clorură de cadmiu) la amur după 96 ore a fost 4/164 ml/1, iar la novac a fost de 5/590 ml/1. Rezultatele studiului arată faptul că acest metal este deosebit de toxic pentru speciile de apă dulce. 


\section{INTRODUCTION}

Group of metal elements for example $\mathrm{Cu}, \mathrm{Fe}, \mathrm{Mn}$ and $\mathrm{Zn}$ are necessary for the survival of living things. Another group of metals are heavy metals. This group of metals, unlike the other group are the non-essential (Di-Giulio and Hinton, 2008; Hedayati et al., 2010). The heavy metals combined with the organic molecules will accumulate in the tissues. This process, is eventually leading to contamination of food and destruction of food chain (Kalay et al., 1999); the heavy metal accumulates in the tissue of living organisms and, moving along the food chain, is causing a threat to food safety. Previous studies have shown that some of the human activities such as the oil extraction dispose industry and hospital waste are leading to increased concentrations of heavy metals such as $\mathrm{Hg}$ and $\mathrm{Cd}$ in the environment. (Tavakoly Sany et al., 2011)

Age, height and weight, gender nutritional habits, the environmental requirements, the concentration of heavy metals in sediment and water, an important determinant of the organs accumulation of heavy metals in fish (Demirak et al., 2006). As well as grass carp and bighead carp are omnivorous fish; they eat their foods from the water surface and bottom sediments (Satari et al., 2007).

The $96 \mathrm{~h}$ LC50 tests is a method for finding the toxicity of various elements; in other words, using this method, the amount of strength and survival of different species, in face of different concentrations of pesticide and other risk factors, can be determined (Hedayati et al., 2014); Whenever the concentration of 96 h LC50 is lower, the toxicity is stronger. Heavy metals have a low 96h LC50 (Johnston et al., 2002).

Until now, few studies have been done on the toxicity of cadmium (96 h LC50) on freshwater fishes, especially grass carp (Ctenopharyngodon idella) and bighead carp (Hypophthalmichthys nobilis). Most studies were detected concentrations of heavy metals in the tissue of marine fish. For example, Farakas et al., 2003; Huang et al., 2003; Juric et al., 2011; Askary Sary, 2012 and Chakeri, 2015. The purpose of this study was to evaluate the effects of acute of cadmium concentrations of on mortality rates and survival of the two species of freshwater fish (grass carp and big head carp).

\section{MATERIAL AND METHODS}

According to primary survey and laboratory facilities, 250 grass carp (weight $40 \pm$ $4 \mathrm{~g}$ ) and 250 Big head carp (weight $12 \pm 2.6 \mathrm{~g}$ ) were prepared from the fish farms in Golestan province and moved to the laboratory (Veniro wet lab, Department of Fisheries, Gorgan University of Agricultural Sciences and Natural Resources). After transferring the fishes to the lab, they have been kept in the 280 liters tanks for the two week (250 liters filling volume) in order to adapt of fish to lab condition. During this time, the fish have been fed three meals a day and equivalent to $3 \%$ of the weight of the fish (Biomar food). The density of fish in each tank was 50 and physicochemical conditions were similar in all tanks (water temperature $28 \pm$ $2^{\circ} \mathrm{C}$, 7-8 $\mathrm{ml} / \mathrm{l}$ dissolved oxygen, $7 / 4$ to $8 / 1 \mathrm{pH}$ and ammonia $0 / 04 \pm 0 / 03 \mathrm{ml} / \mathrm{l}$ ).

After acclimating, 147 fish were selected randomly and were split into seven treatments $(0,0.2,1,2,6,10$ and $15 \mathrm{ml} / \mathrm{l}$ Cadmium chloride) and three repetitions (number of fish in each treatment was 21). Fish were exposed for 96 hours to different concentrations of cadmium chloride. The death count in intervals of 24, 48, 72 and 96 hours and the dead were removed from the tanks of test. The fishes were not fed 18 hours before the main test and during the main test. The physicochemical condition of the water at the time of testing the toxicity of cadmium, minus the concentration of cadmium chloride was similar the previous stage (stage adaptations). 
Acute toxicity of Cadmium was estimated based on Hotos and Vlahos; lethal concentration of Cadmium (for 50\% of the population) in intervals of 24, 48, 72 and 96 hours (24 h LC50), $48 \mathrm{~h}, 72 \mathrm{~h}$ and $96 \mathrm{~h}$ were estimated through probit test with a 95\% confidence. To find the correlation between different concentrations of cadmium on mortality Spearman test (2-tail) was used.

\section{RESULTS AND DISCUSSION}

Specific endpoint results of mortality effects of cadmium for studied fishes are in table 1.

Table 1: Mortality effects of cadmium for studied fish.

\begin{tabular}{|c|c|c|c|c|c|c|c|c|}
\hline \multirow{3}{*}{$\begin{array}{l}\text { Concentration } \\
\text { (mg/l) }\end{array}$} & \multicolumn{8}{|c|}{ Number of mortality } \\
\hline & \multicolumn{2}{|c|}{$24 \mathrm{~h}$} & \multicolumn{2}{|c|}{$48 \mathrm{~h}$} & \multicolumn{2}{|c|}{$72 \mathrm{~h}$} & \multicolumn{2}{|c|}{$96 \mathrm{~h}$} \\
\hline & $\begin{array}{c}\text { Grass } \\
\text { carp }\end{array}$ & Big head & $\begin{array}{l}\text { Grass } \\
\text { carp }\end{array}$ & Big head & $\begin{array}{l}\text { Grass } \\
\text { carp }\end{array}$ & Big head & $\begin{array}{c}\text { Grass } \\
\text { carp }\end{array}$ & Big head \\
\hline 0 & 0 & 0 & 0 & 0 & 0 & 0 & 0 & 0 \\
\hline 0.2 & 0 & 0 & 0 & 0 & 0 & 0 & 0 & 0 \\
\hline 1 & 0 & 0 & 0 & 0 & 0 & 0 & 0 & 0 \\
\hline 2 & 0 & 0 & 0 & 0 & 1 & 0 & 4 & 0 \\
\hline 6 & 3 & 0 & 5 & 1 & 7 & 3 & 14 & 7 \\
\hline 10 & 7 & 5 & 11 & 9 & 18 & 13 & 21 & 21 \\
\hline 15 & 8 & 10 & 15 & 15 & 21 & 21 & 21 & 21 \\
\hline
\end{tabular}

Also, the results showed $96 \mathrm{~h}$ LC50 of cadmium for grass carp was $5.264 \mathrm{mg} / \mathrm{l}$ and for bighead carp was $6.590 \mathrm{mg} / \mathrm{l}$ (Tab. 2); there was significant difference between $96 \mathrm{~h} \mathrm{LC50}$ of cadmium in the grass carp compared to the bighead carp, $(\mathrm{P}<0.05)$. 
Table 2: Lethal concentration of cadmium (96 $\mathrm{h} \mathrm{LC}_{10-95}$ ) for grass carp and big head carp.

\begin{tabular}{|l|c|c|c|c|c|c|c|c|}
\hline \multirow{3}{*}{ Point } & \multicolumn{7}{|c|}{ Concentration (mg/l) } \\
\cline { 2 - 9 } & \multicolumn{2}{|c|}{$24 \mathrm{~h}$} & \multicolumn{2}{|c|}{$48 \mathrm{~h}$} & \multicolumn{2}{c|}{$72 \mathrm{~h}$} & \multicolumn{2}{c|}{$96 \mathrm{~h}$} \\
\cline { 2 - 9 } & $\begin{array}{c}\text { Grass } \\
\text { carp }\end{array}$ & Big head & $\begin{array}{c}\text { Grass } \\
\text { carp }\end{array}$ & Big head & $\begin{array}{c}\text { Grass } \\
\text { carp }\end{array}$ & Big head & $\begin{array}{c}\text { Grass } \\
\text { carp }\end{array}$ & Big head \\
\hline LC10 & 6.748 & 8.628 & 4.911 & 6.795 & 3.793 & 5.791 & 2.530 & 5.096 \\
\hline LC20 & 9.635 & 10.887 & 6.976 & 8.567 & 4.937 & 6.889 & 3.468 & 5.140 \\
\hline LC30 & 11.717 & 12.324 & 8.465 & 9.844 & 5.762 & 7.380 & 4.045 & 5.160 \\
\hline LC40 & 13.496 & 13.551 & 9.737 & 10.955 & 6.467 & 7.657 & 4.143 & 5.334 \\
\hline LC50 & $\mathbf{1 4 . 1 5 9}$ & $\mathbf{1 3 . 6 9 8}$ & $\mathbf{9 . 9 2 6}$ & $\mathbf{1 0 . 9 9 5}$ & $\mathbf{6 . 1 2 6}$ & $\mathbf{7 . 9 8 9}$ & $\mathbf{4 . 1 6 4}$ & $\mathbf{5 . 5 9 0}$ \\
\hline LC60 & 16.822 & 15.845 & 12.115 & 12.975 & 7.785 & 9.621 & 5.804 & 6.846 \\
\hline LC70 & 18.600 & 17.072 & 13.387 & 14.066 & 8.490 & 10.297 & 6.382 & 7.119 \\
\hline LC80 & 20.682 & 18.805 & 14.876 & 15.343 & 9.315 & 11.088 & 7.059 & 7.440 \\
\hline LC90 & 23.570 & 20.500 & 16.941 & 17.114 & 10.459 & 12.186 & 7.998 & 7.884 \\
\hline LC95 & 25.956 & 22.145 & 18.646 & 18.577 & 11.404 & 13.092 & 8.773 & 8.250 \\
\hline
\end{tabular}

Fish, in various concentrations of cadmium chloride, had symptoms of with cadmium poisoning, such as: anxiety, colour vision, increased mucus secretion and death with the open mouth.

Toxic heavy metals are the main group of pollutants in aquatic environments; a large portion of this metal enters aquatic environment due to the human activities (Humtsoe et al., 2007). Monitoring the heavy metals toxicity was important for scientists, nutrition, medical and environmental researchers.

The results of this study showed that cadmium was toxic for grass carp and bighead carp. Lethal concentrations of cadmium (96 h LC50) for grass carp was less than for bighead carp; this difference, in addition to differences in the two species could be due to their size.

Pandey and Madhuri (2014) examined heavy metal toxicity in animals and fish; for this aim they studied on $\mathrm{Hg}, \mathrm{Pb}, \mathrm{Cu}$ and $\mathrm{Cd}$ concentrations in the environments, fishes and other animals. They said that heavy metal toxicity depends on the fish species and their habits. This section of their results was similar to present study.

Studies Chakeri et al. (2013), Vinodhini and Narayanan (2009) and Spehar (1976) found that heavy metal poisoning causes anxiety, increased mucus secretion and eventually death. Also, they said different fish species, had different sensitiveness to heavy metals. The results of the study were similar to our study.

Comparing the present study results with the results of previous studies, the toxicity of cadmium (96 h LC50) had been showed from 1.85-5.30 for Corophium volutator until the 2.91-4.28 $\mathrm{ml} / \mathrm{l}$ for Corophium orientate, depending on the species, nutrition and the environment (Ciarelli, 1994; Onorati et al., 1999; Chen and Folt, 2000). 
Level 96 h LC50 of Cadmium for aquatic species depending on the aquatic species type or metal type is different; for example, Spehar (1976) Level 96 h LC50 of Cadmium for Mugil cephalus and Jordanella floridae had set 28.0 and $2.5 \mathrm{ml} / \mathrm{l}$, respectively. Das and Banerjee (1980) reported 300.0 and $175.0 \mathrm{ml} / \mathrm{l}$ Cadmium for Lebio rohita and Heteropneustes fossilis, respectively. Eventually, Smet and Blust (2011), expressed, after four weeks, the whole population of common carp that were exposed to cadmium (two ml/l) for 96 hours were died.

\section{CONCLUSIONS}

According to the results of this study, grass carp and bighead carp species can be used as biological indicators, howeverhis aim requires further study and higher pervasive. $96 \mathrm{~h} \mathrm{LC}_{50}$ of cadmium chloride for grass carp was $4.164 \mathrm{ml} / \mathrm{l}$ and for big head carp was $5.590 \mathrm{ml} / \mathrm{l}$ that showed cadmium is highly toxic for this species. The effect of two or more heavy metals on the health of fish and toxicity of heavy metal could be the fields of next studuies.

\section{ACKNOWLEDGEMENTS}

The study was done by technical and scientific support of Gorgan University of Agricultural Sciences and Natural Resources. We thank the efforts of Mr. Jafar A. and all those who helped us. 


\section{REFERENCES}

1. Chakeri R., Sajadi M. M., Kamrani E. and Aghajari N., 2015 - Determination of heavy metal (lead and cadmium) concentrations in liver and muscle tissue of Indian mackerel (Rastrelliiger Kanagurta) in Persian Gulf, Iranian Scientific Fisheries Journal, 24, 2, 115-125.

2. Chen C. Y. and Folt C. L., 2000 - Bioaccumulation and diminution of arsenic and lead in a freshwater food web, Environmental Science Technology, 34, 3878-3884.

3. Ciarelli S., 1994 - Guideline for conducting 10-day static sediment toxicity tests using marine or estuarine amphipods, Middelburg, The Netherlands, Report RIKZ-94.031.

4. Das K. K. and Banerjee S. K., 1980 - Cadmium toxicity in fishes, Hydrobiology, 75, 117-121.

5. Giulio R. T. and Hinton D. E., 2008 - The Toxicology of Fishes, Taylor and Francis, 319-884.

6. Demirak A., Yilmaz F., Tuna A. L. and Ozdemir N., 2006 - Heavy metals in water, sediment and tissues of Leuciscus cephalus from a stream in Turkey, Chemosphere, 63, 9, 1451-1458.

7. Hedayati A., Safahieh A., Savar A. and Marammazi J. G., 2010 - Detection of mercury chloride acute toxicity in Yellowfin sea bream, World Journal of Fish and Marine Science, 2, 1, 86-92.

8. Hedayati A., Vajargah M. F., Yalsuyi A. M., Abarghoei S. and Hajiahmadyan M., 2014 - Acute toxicity of pesticide Abamectin on common, Journal of Coastal Life Medicine, 2, 11, 841-844.

9. Huang W. B., 2003 - Heavy Metal Concentration in the Common Benthic Fishes Caught from the coastal Waters of Eastern Taiwan, Journal of Food and Drug Analysis, 11, 4, 324-330.

10. Humtsoe N., Davoodi R., Kulkarni B. G. and Chavan B., 2007 - Effect of arsenic on the enzymes of the robu carp (Labio rohita), The Raffles Bulletin of Zoology, 14, 17-19.

11. Iepure S. and Selescu L., 2009 - Relationship between heavy metals and hyporheic invertebrate community structure in the middle basin of the Arieş River (Transylvania, Romania), Transylvanian Review of Systematical and Ecological Research, 7, 125-148.

12. Jurić I., Visnjic-Jeftic Z., Cvijanović G., Gačić Z., Ovanović L., Skorić S. and Lenhardt M., 2011 - Determination of heavy metal and trace element accumulation in liver, gills, intestine and muscle of sterlet from the Danube by ICP-OES, Microchemical Journal, 91, 77-11.

13. Johnston E. L., Keough M. J. and Qian P. Y., 2002 - Maintenance of species dominance through pulse disturbances to a sessile marine invertebrate assemblage in Port Shelter Hong Kong, Marine Ecology Progress Series, 226, 103-114.

14. Kalay M., Ay P. and Canil M., 1999 - Heavy metal concentration in fish tissues from the Mediterean Sea, The Bulletin of Environmental Contamination and Toxicology, 63, 673-671.

15. Onorati F., Bigongiari N., Pellegrini D. and Giuliani S., 1999 - The suitability of Corophium orientale (Crustacea, Amphipoda) in harbour sediment toxicity bioassessment, Aquatic Ecosystem Health and Management, 2, 465-473.

16. Pandey G. and Madhuri S., 2014 - Heavy Metals Causing Toxicity in Animals and Fishes, Research Journal of Animal, Veterinary and Fishery Sciences, 2, 2, 17-23.

17. Satari M., Shahsavani D. and Shafiei S., 2007 - Systematic ichthyology, Haqshenas Publications, Rasht, Iran, 502.

18. Smet D. H. and Blust R., 2011 - Stress responses and changes in protein metabolism in Carp, during cadmium exposure, Ecotoxicology and Environmental Safety, 48, 255-262.

19. Spehar R. L., 1976 - Cadmium and zinc toxicity in flag fish, Jordanella floridae, Journal of the Fisheries Research Board of Canada, 33, 1939-1945.

20. Sany B. T., Sulaiman A. H., Monazami G. H. and Saleh A., 2011 - Assessment of Sediment Quality According To Heavy Metal Status in the West Port of Malaysia, World Academy of Science, Engineering and Technology, 5, 2, 111-115.

21. Vajargah M. F., Hedayati A., Yalsuyi A. M., Abarghoei S., Gerami M. H. and Farsani H. G., 2014 - Acute toxicity of Butachlor to Caspian Kutum (Rutilus frisii Kutum Kamensky, 1991), Journal of Environmental Treatment Techniques, 2, 4, 155-157.

22. Vinodhini R. and Narayanan M., 2009 - The impact of toxic heavy metals on the hematological parameters in common Carp (Cyprinus Carpio), Journal of Environmental Health Science and Engineering, 6, 1, 23-28. 